\title{
STRATEGI MARKETING SYARIAH DALAM MENINGKATKAN PENJUALAN
}

\section{Putri Amalia Zubaedah, Chiska Nova Harsela}

IAIN Syekh Nurjati Cirebon, Universitas Gunung Jati Cirebon, Indonesia

Email: putt.mafazha@gmail.com, chiska026@gmail.com

Abstrak
Latar belakang: Toko Sembako "AMA" menarik untuk diteliti dari segi pemasarannya yang menggunakan konsep syariah. Konsep syariah yang digunakan diantaranya adalah dengan menanamkan nilai nilai keislaman dalam berjualan seperti nilai kejujuran, keadilan dan keterbukaan. Sedangkan dari strategi pemasarannya, pemasaran syariah disini terdiri dari beberapa karakteristik

Tujuan penelitian:.Penelitian ini bertujuan untuk mengetahui strategi marketing syariah yang dapat meningkatkan penjualan di toko Ama Desa Tegalwangi Kecamatan Weru Kabupaten Cirebon

Metode penelitian: Sesuai dengan permasalahan yang diteliti, jenis penelitian yang digunakan dalam penelitian ini adalah dengan metode kualitatif deskriptif. Yaitu dengan menugmpulkan, menyusun dan mendeskripsikan berbagai dokumen, data yang aktual. Dan data-datanya berasal dari naskah wawancara, foto, dokumen pribadi, catatan atau memo, dan dokumen resmi lainnya.

Hasil penelitian: Strategi pemasaran syariah yang diterapkan di Toko AMA Desa Tegalwangi Kecamatan Weru Kabupaten Cirebon adalah dengan cara pelayanan prima seperti : Ketika toko akan tutup atau libur selalu diberi pemberitahuan terlebih dahulu. Para pelayan toko senantiasa memberi pelayanan prima dengan bersikap ramah dan siap dalam memberikan pelayanan yang terbaik dengan sesuai konsep 7S, yaitu: Salam, Senyum, Sapa, Sopan, Santun, Siap dan Siaga

Kesimpulan: Salah satu strategi yang dapat digunakan untuk meningkatkan penjualan adalah dengan menerapkan strategi pemasaran syariah.

Kata kunci: Strategi, Strategi Pemasaran, Pemasaran Syariah, Penjualan

\section{Abstract}

Background: The "AMA" Sembako Shop is interesting to study from a marketing perspective that uses the sharia concept. The sharia concepts used include instilling Islamic values in selling such as the values of honesty, fairness and openness. Meanwhile, from the marketing strategy, sharia marketing here consists of several characteristic

Research objectives: This study aims to determine sharia marketing strategies that can increase sales at the Ama store, Tegalwangi Village, Weru District, Cirebon Regency.

Research method: In accordance with the problems studied, the type of research used in this research is descriptive qualitative method. Namely by collecting, compiling and describing various documents, actual data. And the data comes from interview scripts, photos, personal documents, notes or memos, and other official documents.

The results of the study: The sharia marketing strategy applied at the AMA Store in Tegalwangi Village, Weru District, Cirebon Regency is by providing excellent service such as: When the store is about to close or on holiday, it is always given advance notice. The shop assistants always provide excellent service by being friendly and ready to provide the best service according to the $7 S$ concept, namely: Greetings, Smiles, Greetings, Polite, Polite, Ready and Alert

Conclusion: One strategy that can be used to increase sales is to implement a sharia marketing strategy.

Keywords: Strategy, Marketing Strategy, Sharia Marketing, Sales

Diterima: 26-11-2021; Direvisi: 6-12-2021; Disetujui: 6-12-2021

Putri Amalia Zubaedah, Chiska Nova Harsela. (2021). Strategi Marketing Syariah Dalam Meningkatkan Penjualan. Co-Value: Jurnal Ekonomi, Koperasi Kewirausahaan Vol 12(3): 9197

E-ISSN:

Published by: $\quad$ https://greenpublisher.id/ 


Strategi Marketing Syariah Dalam Meningkatkan
Penjualan

\section{PENDAHULUAN}

Keadaan pasar yang semakin komplek, menuntut para pedagang atau pengusaha untuk memiliki strategi pemasaran yang baik dan handal, sehingga produk-produknya tidak hanya laku dijual dipasaran, akan tetapi juga mampu bersaing dan bertahan dalam persaingan yang ada.(Mubarok, 2017) Kegiatan promosi suatu badan usaha dilakukan sebaik mungkin yaitu dengan direncanakan, diarahkan, dikendalikan dan dianggarkan sesuai dengan kondisi keuangan di suatu badan usaha tersebut. Dengan adanya upaya kegiatan promosi itu berarti bahwa ada upaya peningkatan penjualan pada suatu badan usaha.(FUADAH, 2021) Meningkatnya penjualan itu juga bisa disebut meningkatnya kegiatan Jual - Beli. Kegiatan jual beli ini konsumen ataupun pelanggan dapat saling melengkapi satu sama lain dengan cara tukar menukar barang atau jasa sesuai kesepakatan.

Dalam hal ini, pemasaran syariah memiliki posisi yang sangat strategis, karena pemasaran syariah merupakan salah satu strategi pemasaran yang didasarkan pada Al-Qur'an dan Sunah Rasulullah SAW. Pemasaran syariah merupakan sebuah disiplin bisnis strategis yang mengarahkan proses penciptaan, penawaran, dan perubahan nilai dari satu pemrakarsa kepada stakeholders-nya, yang dalam keseluruhan prosesnya sesuai dengan akad serta prinsip-prinsip Islam dan muamalah dalam Islam.

Strategi pemasaran syariah berusaha menanamkan perusahaan dan produknya pada pelanggan.(Sutikno et al., 2021) Strategi bertujuan untuk "how to win the market" (bagaimana memenangkan pasar). Seperti yang telah diketahui keadaan dunia yang bersifat dinamis, yang diwarnai dengan adanya perubahan dari waktu ke waktu dan adanya keterkaitan antara satu dengan yang lainnya. Dengan kata lain, strategi pemasaran merupakan serangkaian tujuan dan sasaran, kebijakan dan aturan yang memberi arah kepada usaha-usaha pemasaran perusahaan dari waktu ke waktu, pada masing-masing tingkatan dan acuan serta alokasinya, terutama sebagai tanggapan perusahaan dalam menghadapi lingkungan dan keadaan persaingan yang selalu berubah.(Rusdi, 2019) Penentuan strategi pemasaran harus didasarkan atas analisis lingkungan dan internal perusahaan melalui analisis keunggulan dan kelemahan perusahaan, serta analisis kesempatan dan ancaman yang dihadapi perusahaan dari lingkungannya.(Narto \& Hm, 2020)

Toko Sembako "AMA" merupakan salah satu toko sembako yang ada di kota Cirebon. Toko ini sudah berdiri sejak tahun 2013. Letak tepatnya berada di Jalan Nyi Ageng Matra Blok Desa Rt/Rw 16/04 Desa Tegalwangi Kecamatan Weru Kabupaten Cirebon. Toko ini menjual berbagai macam sembako seperti beras, minyak, gula pasir, pulsa dan sebagainya. Toko ini juga menjual berbagai macam kebutuhan sehari hari seperti sabun, sampo, Pasta gigi dan sebagainya.(Rinaldi, 2019) Biasanya suatu badan usaha itu memiliki satu persepsi gerak langkah dari semua komponen badan usaha dalam rangka implementasi strategi induk dan strategi operasional, tujuan dan berbagai sasaran yang telah ditetapkan untuk dicapai.

Toko Sembako "AMA" menarik untuk diteliti dari segi pemasarannya yang menggunakan konsep syariah. Konsep syariah yang digunakan diantaranya adalah dengan menanamkan nilai nilai keislaman dalam berjualan seperti nilai kejujuran, keadilan dan keterbukaan. Sedangkan dari strategi pemasarannya, pemasaran syariah disini terdiri dari beberapa karakteristik. Untuk mengenali karakteristik pasar dan struktur pasar sangatlah menguntungkan bagi badan usaha untuk dapat tetap bersaing dan survive.(Maldina, 2016) Kelemahan dan keunggulan badan usaha hendaknya dianalisis sehingga menjadi sebuah titik tolak yang kuat untuk badan usaha dalam mengambil keputusan yang efektif dan efisien serta untuk memperkuat posisinya 
dari para pesaing yang ada (Maldina, 2016). Dalam laporan keuangannya pun di Toko Sembako "AMA" ini mengalami peningkatan penjualan. Berdasarkan latar belakang yang telah diuraikan, maka penulis tertarik dan bermaksud melakukan penelitian dengan tujuan untuk mengetahui strategi marketing syariah yang dapat meningkatkan penjualan di toko Ama Desa Tegalwangi Kecamatan Weru Kabupaten Cirebon (H Tarjono et al., 2019).

\section{METODE PENELITIAN}

Adapun penelitian ini dilakukan di Toko Sembako "AMA" yang bertempat di Jalan Nyi Ageng Matra Blok Desa Rt/Rw 16/04 Desa Tegalwangi Kecamatan Weru Kabupaten Cirebon, Jawa Barat 45154, Indonesia. Sesuai dengan permasalahan yang diteliti, jenis penelitian yang digunakan dalam penelitian ini adalah dengan metode kualitatif deskriptif.(Zellatifanny \& Mudjiyanto, 2018) Yaitu dengan menugmpulkan, menyusun dan mendeskripsikan berbagai dokumen, data yang aktual. Dan data-datanya berasal dari naskah wawancara, foto, dokumen pribadi, catatan atau memo, dan dokumen resmi lainya. Data-data yang sudah diperoleh akan diinterpresentasikan dalam pemaparan sehingga penulis dapat memberikan kesimpulan pada penelitian ini.

\section{HASIL DAN PEMBAHASAN}

\section{A. Deskripsi Data Hasil Penelitian}

a. Profil Umum Toko AMA

Toko Sembako "AMA" merupakan salah satu toko sembako yang ada di kota Cirebon. Toko ini sudah berdiri sejak tahun 2013. Letak tepatnya berada di Jalan Nyi Ageng Matra Blok Desa Rt/Rw 16/04 Desa Tegalwangi Kecamatan Weru Kabupaten Cirebon. Toko ini menjual berbagai macam sembako seperti beras, minyak, gula pasir dan sebagainya. Toko ini juga menjual berbagai macam kebutuhan sehari hari seperti sabun, sampo, pasta gigi, pulsa handphone dan sebagainya.(Raharjo, 2012) Biasanya suatu badan usaha itu memiliki satu persepsi gerak langkah dari semua komponen badan usaha dalam rangka implementasi strategi induk dan strategi operasional, tujuan dan berbagai sasaran yang telah ditetapkan untuk dicapai.

Inspirasi membuka toko sembako berawal dari si pemilik toko Yang bercita cita ingin membuka toko sembako seperti retail retail modern seperti ( indomaret, alfamart dll). Dengan pengalaman bekerja di perusahaan retail ternama di indonesia kurang lebih 5 tahun, Ibu Ama maryamah ingin membuka toko sembako yang mampu bersaing di era ini dengan harga terjangkau seperti penjual kaki lima.

b. Modal Awal Dan Asal Nama Toko AMA

a. Modal awal

Bentuk perusahaan ini adalah usaha keluarga, jadi modal awalnya adalah dari pemilik perusahaan dalam hal ini adalah Ibu Ama Maryamah sendiri. Ibu Ama Maryamah tidak membuat perusahaan ini dalam bentuk friendcies (waralaba) seperti perusahaan yang menjadi pesaing pasarnya saat ini. Berawal bulan april 2013 dengan modal kan niat yang tinggi dan uang sebesar 1.500.000,- tuan samsul membuka warung kecil kecilan dan pertama pembukaan warung Ibu Ama hanya mendapat penghasilan kotor sebesar 30.000,- dan seminggu kemudian masih mendapatkan hasil sebesar 150.000,- dan Ibu Ama tidak menyerah sampai di situ, Ibu Ama terus berfikir dan berinovasi berinovasi demi memajukan toko sembakonya. Dan hingga sekarang kurang lebih 6 tahun tokonya 
berkembang yang tadinya hanya berpenghasilan 30.000,- tapi sekarang udah mendapatkan penghasilan kotor rata rata sampai 9.000 .000 perhari.

b. Asal nama Toko AMA

Ibu Ama selaku pemilik Toko Menuturkan pula Asal nama AMA itu berdasarkan nama Sendiri Karena Menurut Ibu Ama kenapa Toko tersebut di beri nama Toko Ama Dalam pengucapan yang simple gk terlalu ribet dan orang juga mudah mengingat nama tersebut.

1. Data Strategi Pemasaran Syariah Di Toko AMA

Dalam dunia bisnis, pemasaran merupakan strategi bisnis yang mengarahkan proses penciptaan, penawaran, dan perubahan nilai dari seorang inisiator kepada pelanggannya.(Hamid \& Zubair, 2019) Menurut ajaran Islam, kegiatan pemasaran harus dilandasi dengan nilai-nilai islami yang dijiwai oleh semangat ibadah kepada Allah dan berusaha semaksimal mungkin kesejahteraan bersama. Menurut prinsip syariah, kegiatan pemasaran harus dilandasi semangat beribadah kepada Tuhan Sang Maha Pencipta, berusaha semaksimal mungkin untuk kesejahteraan bersama, bukan untuk kepentingan golongan apalagi kepentingan sendiri.(Kamaruddin, 2017)

Namun, pada saat awal berdirinya Toko AMA yakni pada tahun 2013, toko ini belum menerapkan strategi pemasaran Islami. Toko ini masih menggunakan pemasaran konvensional dalam berjualan.(Widodo, 2019) Barulah pada saat pemilik Toko mendapatkan ilmu dan pengetahuan tentang strategi pemasaran syariah dari kegemaran membaca buku-buku tentang islam, pemilik Toko mencoba menerapkannya dalam toko miliknya tersebut

Pemasaran di Toko AMA pada saat belum diterapkannya strategi pemasaran syariah adalah pemasaran yang jauh dari nilai nilai islami dan juga karakteristik pemasaran Islami, salah satu contohnya adalah toko yang tetap buka meskipun diwaktu sholat, padahal seharusnya toko tutup sementara saat waktu sholat tiba . selain itu tidak adanya keterbukaan mengenai harga dan kualitas barang dagangan, penjual tak pernah membeberkan mengenai harga asli dan keuntungan yang diambil terhadap pembeli, padahal Rasulullah mencontohkan untuk jujur dan terbuka mengenai harga dan kualitas barang.

\section{B. Pembahasan}

\section{Bagaimana pemasaran di Toko AMA Desa Tegalwangi Kecamatan Weru Kabupaten Cirebon.}

Menurut hasil wawancara penelitian kepada Pemilik Toko berserta Karyawan Toko dan beberapa pelanggan menyimpulkan bahwa pemasaran di Toko AMA Desa Tegalwangi Kecamatan Weru Kabupaten Cirebon pada saat belum diterapkannya strategi pemasaran syariah adalah menggunakan pemasaran konvensional seperti layaknya tokotoko lain sehingga pendapatannya sama seperti toko-toko lain dan bahkan bersaing. Pemasaran di Toko AMA Desa Tegalwangi Kecamatan Weru Kabupaten Cirebon sering terjadi saling banting harga dan sudah tidak peduli lagi tentang halal dan haram, pelayananya pun masih kurang bagus, karyawannya judes-judes, tidak ada keterbukaan mengenai harga barang dan hadiah barang dan pembelinya pun tidak begitu ramai, Pelayanannya juga masih kurang prima, toko pun sering tutup tanpa pemberitahuan sehingga konsumen yang ingin belanja di Toko AMA jadi balik lagi dan tidak jadi belanja. Pelanggan juga jarang di beri diskon atau potongan harga.

\section{Bagaimana strategi pemasaran syariah di Toko AMA Desa Tegalwangi Kecamatan Weru Kabupaten Cirebon}

Menurut hasil wawancara penelitian kepada Pemilik Toko berserta Karyawan Toko dan beberapa pelanggan menyimpulkan bahwa strategi pemasaran syariah yang diterapkan di Toko AMA Desa Tegalwangi Kecamatan Weru Kabupaten Cirebon adalah 
dengan cara pelayanan prima seperti : Ketika toko akan tutup atau libur selalu diberi pemberitahuan terlebih dahulu. Para pelayan toko senantiasa memberi pelayanan prima dengan bersikap ramah dan siap dalam memberikan pelayanan yang terbaik dengan sesuai konsep 7S, yaitu: Salam, Senyum, Sapa, Sopan, Santun, Siap dan Siaga.(Jauhari, 2020) Harga yang ditawarkan terjangkau dan sesuai dengan kualitas barang, sering terdapat diskon atau potongan harga dan juga adanya keterbukaan mengenai kenaikan harga ataupun hadiah barang, dan juga menerapkan sifat sifat terpuji Rasulullah seperti shidiq, amanah, tabligh dan fathanah dalam berbagai aspek berbisnis seperti dalam aspek Product (Produk), Place (Saluran Distribusi), Promotion (Promosi), Price (Harga)

\section{Hal-hal apa saja yang menjadi hambatan pemasaran syariah dan bagaimana} solusinya

Menurut hasil wawancara penelitian kepada Pemilik Toko berserta Karyawan Toko dan beberapa pelanggan menyimpulkan bahwa hal-hal yang menjadi hambatan dalam strategi pemasaran syariah di Toko AMA Desa Tegalwangi Kecamatan Weru Kabupaten Cirebon adalah : kurang menerimanya masyarakat dengan Toko yang sering tutup karena waktu sholat, Susahnya mendidik dan mengajari para karyawan untuk selalu memberikan pelayanan prima kepada para pelanggan, Harga yang sangat tidak stabil dan menghadapi persaingan harga dengan toko toko lain yang sering banting harga demi menarik konsumen, perasaan pelanggan yang tidak pernah puas dengan diskon yang diberikan.

Sedangkan solusi untuk menghadapi hambatan tadi adalah : masyarakat sekitar perlu diberi pengertian dan pembiasaan untuk dapat memahami dan menerima bahwa Toko yang menerapkan strategi pemasaran Islami akan mencontoh perdagangan yang dipraktikkan Rasulullah salah satunya adalah dengan menutup Toko saat waktu sholat tiba. Karyawan harus diberi pelatihan atau upgrading setiap minggunya untuk senantiasa memberikan pelayanan prima kepada pelanggan, Lebih cermat dan update dalam menganalisis harga dipasaran sehingga bisa memberikan harga yang terbaik dan sesuai dengan mutu barang, sekali kali diadakan piknik agar karyawan tidak jenuh dalam melayani pelanggan, memberi pengertian kepada konsumen bahwa harga sudah sesuai dengan kualitas barang (Baihaqi, 2018).

\section{KESIMPULAN}

Berdasarkan penelitian ini dapat disimpulkan bahwa pemasaran di Toko AMA Desa Tegalwangi Kecamatan Weru Kabupaten Cirebon pada saat belum diterapkannya strategi pemasaran syariah adalah menggunakan pemasaran konvensional seperti layaknya toko-toko lain sehingga pendapatannya sama seperti toko-toko lain dan bahkan bersaing.

Strategi pemasaran syariah yang diterapkan di Toko AMA Desa Tegalwangi Kecamatan Weru Kabupaten Cirebon adalah dengan cara pelayanan prima seperti : Ketika toko akan tutup atau libur selalu diberi pemberitahuan terlebih dahulu. Para pelayan toko senantiasa memberi pelayanan prima dengan bersikap ramah dan siap dalam memberikan pelayanan yang terbaik dengan sesuai konsep 7S, yaitu: Salam, Senyum, Sapa, Sopan, Santun, Siap dan Siaga. Harga yang ditawarkan terjangkau dan sesuai dengan kualitas barang, sering terdapat diskon atau potongan harga dan juga adanya keterbukaan mengenai kenaikan harga ataupun hadiah barang, dan juga menerapkan sifat sifat terpuji Rasulullah seperti shidiq, amanah, tabligh dan fathanah dalam berbagai aspek berbisnis seperti dalam aspek Product (Produk), Place (Saluran Distribusi), Promotion (Promosi), Price (Harga). 
Hal-hal yang menjadi hambatan dalam strategi pemasaran syariah di Toko AMA Desa Tegalwangi Kecamatan Weru Kabupaten Cirebon adalah : kurang menerimanya masyarakat dengan Toko yang sering tutup karena waktu sholat, Susahnya mendidik dan mengajari para karyawan untuk selalu memberikan pelayanan prima kepada para pelanggan, Harga yang sangat tidak stabil dan menghadapi persaingan harga dengan toko toko lain yang sering banting harga demi menarik konsumen, perasaan pelanggan yang tidak pernah puas dengan diskon yang diberikan. Sedangkan solusi untuk menghadapi hambatan tadi adalah : masyarakat sekitar perlu diberi pengertian dan pembiasaan untuk dapat memahami dan menerima bahwa Toko yang menerapkan strategi pemasaran Islami akan mencontoh perdagangan yang dipraktikkan Rasulullah salah satunya adalah dengan menutup Toko saat waktu sholat tiba. Karyawan harus diberi pelatihan atau upgrading setiap minggunya untuk senantiasa memberikan pelayanan prima kepada pelanggan, Lebih cermat dan update dalam menganalisis harga dipasaran sehingga bisa memberikan harga yang terbaik dan sesuai dengan mutu barang, sekali kali diadakan piknik agar karyawan tidak jenuh dalam melayani pelanggan, memberi pengertian kepada konsumen bahwa harga sudah sesuai dengan kualitas barang.

\section{BIBLIOGRAFI}

Baihaqi, I. (2018). Analisis Pengendalian Kualitas Baglog Jamur Tiram Putih (Pleourotus Ostreatus)(Studi Kasus Di Cv. Agaricus Sido Makmur Sentosa, Lawang, Kabupaten Malang). Universitas Brawijaya.

FUADAH, K. (2021). Analisis Strategi Promosi Melalui Penerapan Sales Promotion Dalam Perspektif Prinsip Syariah (Studi Kasus Pada Toko Pertanian Tani Berkah Desa Kubangpari Kecamatan Kersana Kabupaten Brebes). IAIN Syekh Nurjati Cirebon.

H Tarjono, M. M., H Ahmad Munajim, M. M., Barnawi, M. S. I., \& Ridwan, T. (2019). STRATEGI MARKETING SYARIAH DAPAT MENINGKATKAN PENJUALAN DI TOKO AMA TEGALWANGI KECAMATAN WERU KABUPATEN CIREBON.

Hamid, A., \& Zubair, M. K. (2019). Implementasi Etika Islam Dalam Pemasaran Produk Bank Syariah. BALANCA: Jurnal Ekonomi Dan Bisnis Islam, 1(1), 16-34.

Jauhari, A. (2020). Strategi Pemasaran dalam Perspektif Islam (Studi Kasus PT Mega Indah Sari Timor, Gowa). Universitas Islam Negeri Alauddin Makassar.

Kamaruddin, K. (2017). STRATEGI PEMASARAN TERHADAP PENINGKATAN VOLUME PENJUALAN GAS ELPIJI PERSPEKTIF EKONOMI ISLAM. Laa Maisyir: Jurnal Ekonomi Islam, 4(1).

Maldina, E. Y. (2016). STRATEGI PEMASARAN ISLAMI DALAM MENINGKATKAN PENJUALAN PADA BUTIK CALISTA.[SKRIPSI]. UIN RADEN FATAH PALEMBANG.

Mubarok, N. (2017). Strategi Pemasaran Islami Dalam Meningkatkan Penjualan Pada Butik Calista. I-ECONOMICS: A Research Journal on Islamic Economics, 3(1), 73-92.

Narto, N., \& Hm, G. B. (2020). Penguatan Strategi Pemasaran Pudak di Tengah Pandemi Covid-19 untuk Meningkatkan Keunggulan Bersaing Usaha Mikro Kecil Menengah Kota Gresik. Jurnal INTECH Teknik Industri Universitas Serang Raya, 6(1), 48-54.

Raharjo, B. (2012). Bahasa Pada Dialog Iklan Produk-Produk Pt Unilever Tbk Ditelevisi Swasta Indonesia (Kajian Pragmatik). UNS (Sebelas Maret University).

Rinaldi, F. R. (2019). PENGEMBANGAN SISTEM INFORMASI PERSEDIAAN BARANG DI TOKO DUA PUTRA. Universitas Atma Jaya Yogyakarta. 
Rusdi, M. (2019). Strategi Pemasaran untuk Meningkatkan Volume Penjualan pada Perusahaan Genting UD. Berkah Jaya. Jurnal Studi Manajemen Dan Bisnis, 6(2), $83-88$.

Sutikno, R. I., Alfaini, L. Z., \& Syabrina, W. P. (2021). MENINGKATKAN PENJUALAN MELALUI STRATEGI PEMASARAN DIGITAL PADA UMKM KONVEKSI SUCEX KAOS SUMEDANG JALAN SUKATALI RAYA, KECAMATAN SITURAJA, KABUPATEN SUMEDANG. Prosiding Seminar Nasional Pengabdian Masyarakat LPPM UMJ, 1(1).

Widodo, S. (2019). Strategi Pemasaran Dalam Meningkatkan Siklus Hidup Produk (Product Life Cycle). JEpa, 4(1), 84-90.

Zellatifanny, C. M., \& Mudjiyanto, B. (2018). Tipe penelitian deskripsi dalam ilmu komunikasi. Diakom: Jurnal Media Dan Komunikasi, 1(2), 83-90.

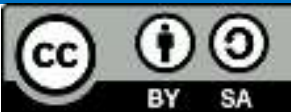

This work is licensed under a Creative Commons Attribution-ShareAlike 4.0 International License 